\title{
Nervous System Elapsed Time
}

National Cancer Institute

\section{Source}

National Cancer Institute. Nervous System Elapsed Time. NCI Thesaurus. Code C162202.

The interval between two nervous system findings reference time points. 